\title{
The Measurement of Muscle Mass in Children Using $\left[{ }^{15} \mathrm{~N}\right]$ Creatine
}

\author{
DAVID PICOU, (44) P. J. REEDS, A. JACKSON, AND N. POULTER \\ Tropical Metabolism Research Unit, University of the West Indies, Mona, Kingston, Jamaica, West Indies
}

\begin{abstract}
Extract
In eight infants and children who had recovered from proteinenergy malnutrition (PEM), muscle mass was estimated by measuring creatine turnover by an isotope dilution technique using $\left[{ }^{15} \mathrm{~N}\right]$ creatine, creatine concentration, and urinary creatinine output. Creatine turnover varied from 1.5 to $2.6 \%$ of the muscle creatine pool per day and muscle creatine concentration ranged from 1.7 to $3.9 \mu \mathrm{g} / \mu \mathrm{g}$ muscle DNA. Muscle mass was between $15 \%$ and $37 \%$ of total body weight. The results indicate that daily creatinine output is not a reliable indicator of muscle mass in children who have recently recovered from severe $\mathrm{PEM}$.
\end{abstract}

\section{Speculation}

Short term fluctuations in the daily creatinine output in young children may be due to variations in muscle creatine concentration since creatine turnover, in the individual subject, remains re markably constant. The wide variation in the proportion of body weight that is muscle may reflect significant body composition changes in fat, water, and muscle in children who have recovered from severe protein-energy malnutrition.

Skeletal muscle is the major component of lean body mass and is also the largest protein reservoir in the body. However, there is no accurate method for measuring muscle mass in man. A limited number of whole body dissection studies have been performed in relatively well nourished and in severely malnourished children $(16,18,27)$. This direct method has limitations because it is difficult to ensure complete dissection of all muscle tissue, variable amounts of water and other fluids are lost during and after dissection, and studies are done at varying times after death. It is therefore difficult to extrapolate these findings to the dynamic situation in the living individual. Of the alternative and indirect methods of estimating muscle mass, that based on the $24-\mathrm{hr}$ creatinine excretion is most widely used. The strong association between creatinine excretion and body weight led to the suggestion that muscle mass could be predicted from the daily output of urinary creatinine (24). The relationship has received continuing attention $(7,9,21,31)$ and constants $(17,31)$ or equations $(8,9)$ have been derived which seek to relate 24 -hr urinary creatinine output to muscle mass.

The relationship is based on the observations that urinary creatinine is the sole breakdown product of creatine (3) and that more than $90 \%$ of body creatine is located in skeletal muscle (23, 35 ). Furthermore, the breakdown of creatine, or more accurately, creatine phosphate to creatinine, is a nonenzymic process (5) that occurs at a fixed rate. Under normal circumstances the rate of formation and excretion of urinary creatinine will therefore depend on the size and turnover rate of the creatine pool and the relationship between muscle mass and creatinine excretion will depend on the concentration of creatine in muscle.

Creatine catabolism has been measured with isotopically labeled creatine in normal individuals $(13,19,21)$ and is remarkably constant although there is sufficient variation between individuals to affect the creatinine excretion per unit of body creatine. The concentration in muscle also shows individual variation (1). When the daily excretion of urinary creatinine is used to estimate muscle mass, it is important to recognize that both creatine turnover (13, 35 ) and creatine content of muscle (1) vary in the individual in differing clinical states. Other workers have pointed out the un reliability of using a single constant to relate muscle mass to creatinine excretion (21). In the present study we have measured creatine turnover and creatine concentration in muscle in estimating muscle mass in children.

\section{THEORETICAL CONSIDERATIONS AND CALCULATIONS}

Since more than $90 \%$ of body creatine is found in muscle, from a knowledge of the size of the creatine pool and the concentration of creatine in muscle, muscle mass can be estimated

Muscle mass $(\mathrm{kg})$ creatine pool $(\mathrm{g})$

creatine concentration in muscle ( $\mu \mathrm{g} / \mathrm{mg}$ wet weight of muscle)

The size of the creatine pool may be estimated by an isotope dilution technique. A tracer dose of ${ }^{15} \mathrm{~N}$-labeled creatine is administered and after equilibration the size of the creatine pool can be calculated as follows: creatine pool $=\left[\left(\right.\right.$ dose of $\left[{ }^{15} \mathrm{~N}\right]$ creatine remaining $) /\left(\right.$ degree of enrichment of muscle $\left[{ }^{15} \mathrm{~N}\right]$ creatine $\left.)\right]$. This approach has a number of disadvantages. In order to calculate the dose of $\left[{ }^{15} \mathrm{~N}\right]$ creatine remaining after equilibration, the total loss of ${ }^{15} \mathrm{~N}$ up to isotopic equilibrium must be measured accurately. It is technically difficult to ensure complete urine and stool collections over $72 \mathrm{hr}$, the period of equilibration, in infants and young children. Also, the degree of enrichment of urinary total nitrogen with ${ }^{15} \mathrm{~N}$ towards the end of the equilibration period is so low that accurate measurements of isotope enrichment are not technically possible. It has also been shown in rabbits that after intravenous injection of $\left[{ }^{14} \mathrm{C}\right]$ creatine, up to $25 \%$ of the dose given was secreted into the gastrointestinal tract where it was destroyed by micro-organisms (14). There is therefore a real possibility that after administering a dose of $\left[{ }^{15} \mathrm{~N}\right]$ creatine a significant proportion would neither mix with body creatine nor be accounted for in stool or urine. A final disadvantage is that muscle samples weighing several grams would be required to determine the enrichment of muscle creatine.

In order to avoid these difficulties another method to measure the size of the creatine pool was developed. After intravenous injection of $\left[{ }^{15} \mathrm{~N}\right]$ creatine and its equilibration with muscle creatine, the rate of loss of label as urinary $\left[{ }^{15} \mathrm{~N}\right]$ creatinine reflects the rate of breakdown of the muscle creatine pool. This is based on the observations that muscle creatine is not normally excreted as such, its sole nonreutilizable excretory end product is urinary creatinine (3), and the breakdown of creatine phosphate to creatinine is a nonenzymic process (5) and occurs at a fixed rate. 
It follows that the size of the muscle creatine pool can be calculated as follows:

$$
\begin{aligned}
& \text { Creatine pool }(\mathrm{mg}) \\
& =\frac{\text { urinary creatinine excretion }(, \mathrm{g} / \text { day })}{\text { turnover of muscle creatine }(\% / \text { day })} \times 100 \times 1.159
\end{aligned}
$$

where creatine turnover is defined as the percentage of the muscle creatine pool that is broken down and excreted per day and 1.159 is equal to the ratio of the molecular weight of creatine to that of creatinine. Turnover was calculated as the slope of the line obtained from the semilog plot of the daily urinary excretion of excess ${ }^{15} \mathrm{~N}$ in creatinine as a function of time. The assumptions underlying this method are as follows. (l) Isotopic equilibration occurs in the creatinine precursor pool within 3 days after isotope administration. (2) Muscle creatine is the sole precursor of urinary creatinine. (3) The fractional rate at which creatinine is formed from creatine and excreted remains constant during the period of measurement. The validity of these assumptions is discussed under Results.

\section{MATERIALS AND METHODS}

Eight male Jamaican infants and children who had achieved full clinical recovery from protein-energy malnut rition were studied in a metabolic ward. Their ages ranged from 4 to 27 months (mean 14.8 months) and their weights, as a percentage of their expected weight for height, using the 50th percentile of the Boston standard, ranged from 90 to $107 \%$ with a mean of $98 \%$ (Table 1). All children were afebrile and free from overt infection during their studies. Body weight was measured daily and length once a week. The diet consisted of a proprietary milk mixture with added arachis oil and provided $135 \mathrm{kcal}$ and $3.1 \mathrm{~g}$ protein/100 $\mathrm{ml}$ feeding (29). Full and informed parental consent was obtained for each study

The children were given a single intravenous injection of sterile $\left[{ }^{15} \mathrm{~N}\right]$ creatine $\left(30\right.$ atom \%) in $0.9 \% \mathrm{NaCl}$ at a dose of $1 \mathrm{mg}{ }^{15} \mathrm{~N} / \mathrm{kg}$ body weight. The synthesis of $\left[{ }^{15} \mathrm{~N}\right]$ creatine is described below. The time of injection was noted. On day 3 and at intervals of 5-7 days for 3-4 weeks, urine was carefully collected on ice to minimize the interconversion of creatine and creatinine (32) for timed periods of approximately $24 \mathrm{hr}$ and stored at $-10^{\circ}$ until analyzed. At $13.00 \mathrm{hr}$ on day 4 a sample of muscle was obtained either by percutaneous needle biopsy of the quadriceps femoris (25) or by open biopsy of the pectoralis major (34). The biopsy material was lightly blotted on filter paper to remove any adhering blood; any fat or connective tissue was removed by dissection with needles. The muscle sample was weighed at timed intervals on a torsion balance which allowed the original wet weight to be calculated (25). The sample was then frozen in liquid air and stored at $-20^{\circ}$ until analyzed.

Table 1. Anthropometric measurements in eight male children after recovery from severe protein-energy malnutrition

\begin{tabular}{lccccc}
\hline Subject & Age, mo & $\mathrm{Wt}, \mathrm{kg}$ & $\mathrm{Ht}, \mathrm{cm}$ & $\begin{array}{c}\text { Expected } \\
\text { wt for } \\
\text { age, \% }\end{array}$ & $\begin{array}{c}\text { Expected } \\
\text { wt for } \\
\mathrm{ht}, \%\end{array}$ \\
\hline$R W$ & 4 & 4.28 & 56.5 & 68 & 90 \\
$D A$ & 12 & 9.36 & 72.5 & 94 & 100 \\
$H C$ & 13 & 5.22 & 58 & 51 & 101 \\
$D J$ & 13 & 7.93 & 67 & 78 & 102 \\
$B J$ & 15 & 9.52 & 75 & 87 & 95 \\
$O J$ & 16 & 8.61 & 73 & 78 & 90 \\
$M T$ & 18 & 10.85 & 80.5 & 94 & 97 \\
$C R$ & 27 & 13.18 & 86 & 101 & 107 \\
Mean & 14.8 & & & 82 & 98 \\
\pm SD & 6.5 & & & \pm 15.3 & \pm 7.7 \\
\hline
\end{tabular}

SYNTHESIS OF $\left[{ }^{15} \mathrm{~N}\right]$ CREATINE

$\left[{ }^{15} \mathrm{~N}\right]$ Glycine (95 atom \% enriched) (34) was converted to $\left[{ }^{15} \mathrm{~N}\right]$ sarcosine $(11)$. The acid solution of $\left[{ }^{15} \mathrm{~N}\right]$ sarcosine was applied to a $25-\mathrm{ml}$ column of Dowex 50 ion exchange resin $\left(\mathrm{H}^{+}\right.$, 100-200 mesh) which was washed to neutrality with water and $\left[{ }^{15} \mathrm{~N}\right]$ sarcosine eluted with $7 \%$ ammonia solution in three $25-\mathrm{ml}$ fractions. The crude sarcosine obtained on reducing these fractions to dryness was pooled and recrystalized from boiling $95 \%$ ethanol. Sarcosine was reacted with cyanamide (37) in the presence of ammonia to form creatine (4). Recrystallized $\left[{ }^{15} \mathrm{~N}\right]$ creatine was pure on the basis of melting point, infrared spectrum, and enzymic assay.

\section{URINE ANALYSES}

The Jaffe method was used to measure creatinine content of urine before and after chromatographic treatment (see below) and the values obtained were not significantly different. It was concluded that in these urine samples the contribution of nonspecific chromogen to the color developed in the Jaffe reaction was negligible and therefore the preliminary step of absorbing nonspecific chromogens with Lloyd's reagent was omitted. Creatinine was isolated from urine for mass spectrometry as follows. Urine containing $20 \mathrm{mg}$ creatinine was adjusted to $\mathrm{pH} 2.5-3.0$ with $6 \mathrm{M}$ $\mathrm{HCl}$ and placed on a column $(25 \times 1 \mathrm{~cm})$ containing Dowex 50 resin $\left(\mathrm{Na}^{+}, 100-200\right.$ mesh) equilibrated with water. One hundred milliliters of sodium citrate buffer $\left(0.05 \mathrm{M} \mathrm{Na}^{+}\right.$and $\left.\mathrm{pH} 5.0\right)$ were allowed to run through the column and creatinine was eluted from the column by adding $120 \mathrm{ml} 0.1 \mathrm{M}$ sodium phosphate buffer, $\mathrm{pH}$ 6.60. Ten-milliliter fractions of eluate were collected and analyzed for creatinine content. Virtually all of the creatinine was accounted for in four fractions which also contained trace amounts of tyrosine and phenylalanine. Creatinine was separated from these amino acids by the addition of phosphotungstic acid $(10 \% \mathrm{w} / \mathrm{v})$ to form the highly insoluble precipitate, creatinine phosphotungstate. The precipitate was washed once with water, dried in vacuo, and submitted to Kjeldahl digestion for $24 \mathrm{hr}$. Nitrogen in the sample was liberated for mass spectrometry (30) and isotopic abundance determined on an AEI mass spectrometer, model MS3 (38), using the double collector technique. The purity of creatinine isolated from urine by this procedure was checked by comparing the observed and theoretical isotope abundance of $\left[{ }^{15} \mathrm{~N}\right] \mathrm{creatinine}$ isolated from a urine sample to which was added a known amount of pure $\left[{ }^{15} \mathrm{~N}\right] \mathrm{creatinine}$. The observed atom per cent excess was between $98 \%$ and $102 \%$ of the predicted value.

Urinary creatine was isolated by a similar procedure. Urine containing $20 \mathrm{mg}$ creatine was adjusted to $\mathrm{pH} 3.0$ by the addition of $6 \mathrm{M} \mathrm{HCl}$ and placed on a column $(25 \times 1 \mathrm{~cm})$ containing Dowex 50 resin $\left(\mathrm{Na}^{+}, 100-200\right.$ mesh). One hundred milliliters of sodium citrate buffer $\left(0.2 \mathrm{M} \mathrm{Na}^{+}, \mathrm{pH} 3.4\right)$ were allowed to run through the column and creatine was eluted with $50 \mathrm{ml}$ sodium citrate buffer $\left(0.05 \mathrm{M} \mathrm{Na}^{+}, \mathrm{pH} 5.0\right)$. Samples containing creatine were prepared for mass spectrometry by the methods described above. Creatine content in urine was first estimated by an enzymic method (2) and later by a colorimetric method (12) which gave identical results and was therefore adopted.

\section{MUSCLE ANALYSES}

The muscle sample weighing 7-10 mg was homogenized in deionized water at $4^{\circ}$ in a motor-driven all glass Duall tissue grinder (39) and divided into aliquots. Creatine was measured by an enzyme method (2), collagen and noncollagen protein were separated (34), and the protein in each fraction was determined by the Lowry method (22). DNA was assayed by the method of Kissane et al. (20), with minor modifications.

\section{RESULTS}

The total amount of excess of ${ }^{15} \mathrm{~N}(40)$ excreted as urinary $\left[{ }^{15} \mathrm{~N}\right] c$ reatinine per day was plotted on semilogarithmic paper as a 
function of time and a typical result is shown in Figure 1. The lines obtained from a least squares fit represented a single log-linear process and regression analysis yielded correlation coefficients of 0.843-0.978 in eight subjects (Table 2). In one study (Fig. 1, BJ) when values for excess ${ }^{15} \mathrm{~N}$ excreted on days $l$ and 2 were plotted, they fell on a steep slope that was different from the straight line obtained from the rest of the values. These results provide good evidence in support of the assumptions that isotopic equilibration occurs by day 3 in the creatinine precursor pool and that muscle creatine turnover is constant over the period of measurement. The validity of the assumption that muscle creatine is the sole precursor of urinary creatinine was tested by comparing the enrichment of creatine isolated from muscle with that of urinary creatinine in one subject $(M T)$.

Three days after the intravenous administration of $\left[{ }^{15} \mathrm{~N}\right]$ creatine a sample of muscle was obtained from the rectus abdominis muscle at an elective operation for repair of an umbilical hernia. Urine was collected during the $24 \mathrm{hr}$ immediately preceding the operation. The atom per cent excess of muscle creatine was 0.085 as compared with 0.099 for urinary creatinine. This close agreement supports the assumptions that isotopic equilibration had been achieved in the muscle creatine pool and that the latter was the immediate precursor of urinary creatinine.

The creatine turnover rates in eight subjects are shown in Table 2. They ranged from $1.53-2.63 \% / 24 \mathrm{hr}$ and illustrate the wide variation between individuals.

The concentration of creatine in muscle also varied among individuals irrespective of whether the results were expressed per unit wet weight of muscle, per unit noncollagen protein, or per unit DNA (Table 3).

In three studies the amount of urinary creatine excreted per day and its degree of enrichment were measured and are shown in Table 4. From these data the turnover and the size of the nonmuscle creatine pool were calculated as for the muscle creatine pool. The degree of enrichment of urinary creatine was substantially less than that of urinary creatinine and the turnover rate of the nonmuscle creatine pool was 4-6 times faster than that of the muscle creatine pool. Table 5 shows the values of muscle mass calculated from muscle creatine turnover, creatinine excretion, and muscle mass equivalent to the excretion of $1 \mathrm{~g}$ creatinine in $24 \mathrm{hr}$. Muscle mass as a percentage of total body weight varied from 15 to 37 (mean $21.8 \pm 7.8 \%$ ) and the muscle mass equivalent to a daily excretion of $1 \mathrm{~g}$ creatinine ranged from 14 to $32 \mathrm{~kg}$ (mean $18.6 \mathrm{~kg} \pm 6.60 \mathrm{~kg}$ ).

\section{DISCUSSION}

Muscle mass has been estimated indirectly from the daily creatinine excretion, assuming that $1 \mathrm{~g}$ creatinine excreted/24

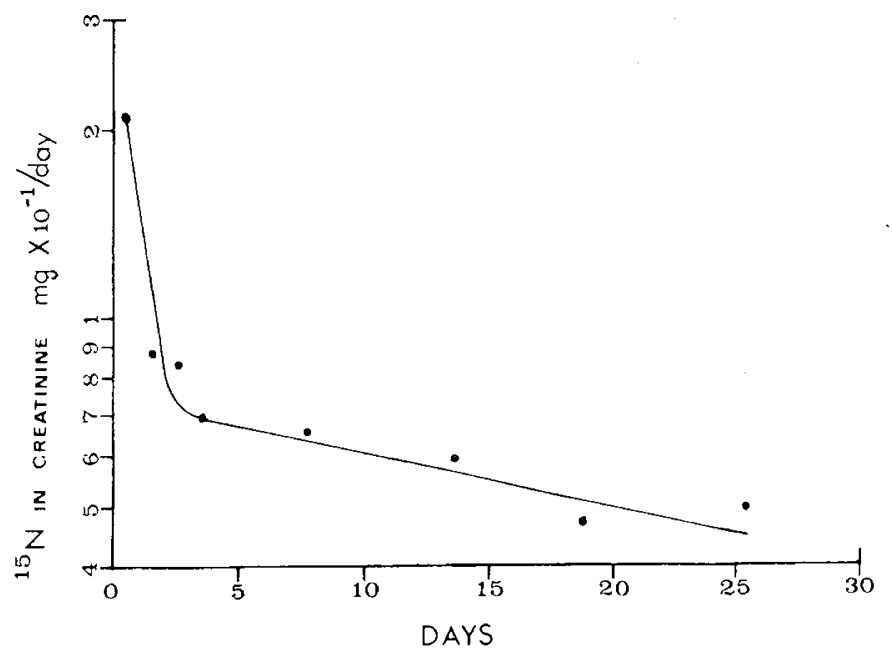

Fig. 1. Semi-log plot of ${ }^{15} \mathrm{~N}$ excreted as urinary $\left[{ }^{15} \mathrm{~N}\right]$ creatinine per 24 hr as a function of time.
Table 2. Creatine turnover in eight children who recovered ${ }^{1}$

\begin{tabular}{lccc}
\hline Subject & $\begin{array}{c}\text { Creatine } \\
\text { turnover, } \\
\% / 24 \mathrm{hr}\end{array}$ & $n$ & $r$ \\
\hline$R W$ & 1.53 & 4 & 0.954 \\
$D A$ & 2.63 & 4 & 0.978 \\
$H C$ & 2.33 & 4 & 0.869 \\
$D J$ & 1.87 & 4 & 0.929 \\
$B J$ & 2.43 & 4 & 0.946 \\
$O J$ & 2.42 & 5 & 0.973 \\
$M T$ & 2.38 & 5 & 0.938 \\
$C R$ & 1.61 & 4 & 0.843 \\
Mean & 2.15 & & \\
\pm SD & 0.42 & &
\end{tabular}

${ }^{1}$ Creatine turnover is expressed as the percentage of the creatine pool that is broken down per $24 \mathrm{hr}$. $n$ denotes the number of observations in each study and the correlation coefficient $r$ is calculated from linear regression analysis of the daily excretion of excess ${ }^{15} \mathrm{~N}$ against time.

Table 3. Muscle biopsy data: Concentration of creatine in muscle expressed relative to wet weight, noncollagen protein $(N C P)$, and DNA in muscle

\begin{tabular}{lccc}
\hline & Muscle & Creatine & Concentration \\
\hline \multirow{2}{*}{ Subject } & $\begin{array}{c}\mu \mathrm{g} / \mathrm{mg} \\
\text { wet } \mathrm{wt}\end{array}$ & $\begin{array}{c}\mu \mathrm{g} / \mathrm{mg} \\
\mathrm{NCP}\end{array}$ & $\mu \mathrm{g} / \mu \mathrm{g}$ DNA \\
\hline$R W$ & 2.95 & 23.3 & 2.50 \\
$D A$ & 2.92 & 21.4 & 1.69 \\
$H C$ & 3.00 & 24.5 & 2.84 \\
$D J$ & 3.59 & 21.8 & 1.88 \\
$B J$ & 3.46 & 24.1 & 3.85 \\
$O J$ & 3.45 & 22.6 & 1.93 \\
$M T$ & 3.32 & 35.0 & 2.61 \\
$C R$ & 2.25 & 15.1 & 2.64 \\
Mean & 3.12 & 23.5 & 2.49 \\
\pm SD & 0.43 & 5.5 & 0.48 \\
\hline
\end{tabular}

$\mathrm{hr}$ is equivalent to $20 \mathrm{~kg}$ muscle $(6,17)$. In deriving this factor of 20 , muscle mass was estimated in normal children by assuming that muscle intracellular water was a constant percentage of total intracellular water. This assumption was based on measurements in the rat. Even if this assumption were valid in normal children, it is dubious that it, or the derived factor of 20 , is applicable to the malnourished child in whom there are gross abnormalities and wide variations in body composition $(16,26,33)$. Recent work in this unit has shown that intracellular water content of leukocytes was greater in malnourished children at the start of refeeding than in recovered children (28). Implicit in the use of a constant factor relating creatinine excretion to muscle mass are two concepts which were examined in this study. The first is that for a given muscle mass containing a given amount of creatine, a constant proportion of the latter is broken down and excreted as creatinine per day. However, the rates of creatine turnover found in this study varied from 1.5 to $2.6 \% / 24 \mathrm{hr}$ (Table 2). The other implicit concept is that the concentration of creatine in muscle is constant. This is not borne out by the data reported here which show that there was variation in the creatine content of muscle whether expressed on the basis of wet weight, noncollagen muscle protein, or muscle DNA (Table 3).

The basis of the present method of estimating muscle mass depends on measuring the size of the body or muscle creatine pool from the rate of loss of isotope following a single dose of labeled $\left[{ }^{15} \mathrm{~N}\right]$ creatine. A similar approach has been used recently $(21)$. The pattern of excretion of label is consistent with a model of 
washout from a simple one-compartment system. However, a factor to be taken into account is the relatively large amounts of urinary creatine excreted by young children (10), an observation confirmed in this study. It was found that creatine excretion was unrelated to either age or body weight. The isotopic abundance of urinary creatine was $20-50 \%$ that of $\left[{ }^{15} \mathrm{~N}\right]$ creatinine in the same urine sample (Table 4). This implies that there are different precursor pools for urinary creatinine and creatine and that they are not in rapid equilibrium. Furthermore, the turnover rate of the precursor pool of urinary creatine appeared to be about 4--5 times as rapid as that of the precursor pool of creatinine. The size of the rapidly turning over creatine pool was calculated to be approximately $4-12 \%$ of the size of the creatinine precursor pool. It appears therefore that there are two pools of creatine, a small pool with a fast turnover because of excretion of creatine, and a much larger pool, the muscle creatine pool, which turns over at a slower rate through the formation and excretion of creatinine. Fitch et al. (13) have proposed a similar model to explain the creatinuria in patients and animals with muscular dystrophy. In the study reported here, the presence of a second creatine pool did not significantly affect the measurements of either turnover or pool size of body creatine because this secondary pool was of low isotopic abundance and small size and had a rapid turnover.

Muscle mass as a percentage of body weight varied widely and this may reflect individual differences in the proportions of fat, water, and muscle in the body. Although the mean value of
$18.6 \mathrm{~kg}$ muscle mass $/ \mathrm{g}$ creatinine excreted $/ 24 \mathrm{hr}$ is similar to that obtained by other workers (16), the individual values ranged from 13.8 to $31.9 \mathrm{~kg}$ muscle $/ \mathrm{g}$ daily creatinine output and the standard deviation was $\pm 35 \%$ of the mean value (Table 5 ). This large and unpredictable variation reduces the value of using a constant factor in predicting muscle mass on an individual basis from daily creatinine output. The data presented show that small but significant variations occur between individuals in both creatine turnover and muscle creatine concentration and that both of these parameters need to be measured in order to obtain a reasonably accurate estimate of muscle mass. The method described should have important applications in the study of body composition. One such application is the estimation of muscle mass in severe protein-energy malnutrition, a study which will be reported separately.

\section{SUMMARY}

A method to estimate muscle mass in children was developed. A tracer dose of $\left[{ }^{15} \mathrm{~N}\right]$ creatine was injected intravenously to label total body creatine, nearly all of which is in muscle. The loss of excess ${ }^{15} \mathrm{~N}$ in urinary creatinine followed a monoexponential process from which the turnover rate in the muscle creatine pool was determined. From a knowledge of creatine turnover and creatinine output in urine, the size of the muscle creatine pool was calculated. Muscle mass was then estimated from the creatine pool

Table 4. Comparison of isotopic enrichments of urinary creatine and creatinine and of turnover rates of muscle creatine (MC) and nonmuscle creatine $(N M C)$ pools in three children

\begin{tabular}{|c|c|c|c|c|c|}
\hline & \multicolumn{2}{|c|}{ Urinary creatine } & \multirow{2}{*}{$\begin{array}{c}\text { Urinary } \\
\text { creatinine, } \\
\text { atom } \% \text { excess }{ }^{1}\end{array}$} & \multirow{2}{*}{$\frac{\text { Turnover }}{\% \mathrm{MC} / 24 \mathrm{hr}}$} & Rate \\
\hline & $\mathrm{mg} / 24 \mathrm{hr}$ & Atom $\%$ excess $^{1}$ & & & $\% \mathrm{NMC} / 24 \mathrm{hr}$ \\
\hline \multicolumn{6}{|l|}{ Subject BJ } \\
\hline Day 3 & 51.3 & 0.1122 & 0.1974 & 2.43 & 8.0 \\
\hline Day 7 & 79.6 & 0.0477 & 0.1695 & & \\
\hline Day 14 & 56.2 & 0.0338 & 0.1438 & & \\
\hline Day 6 & 72.2 & 0.0869 & 0.1229 & 1.87 & 6.3 \\
\hline Day 14 & 185.5 & 0.0265 & 0.0862 & & \\
\hline Day 21 & 112.0 & 0.0261 & 0.0683 & & \\
\hline \multicolumn{6}{|c|}{ Subject $M T$} \\
\hline Day 3 & 44.6 & 0.0993 & 0.0994 & 2.38 & 7.4 \\
\hline Day 9 & 114.1 & 0.0486 & 0.0684 & & \\
\hline
\end{tabular}

${ }^{1}$ Atom per cent of ${ }^{15} \mathrm{~N}$ in excess of the natural abundance of ${ }^{15} \mathrm{~N}$.

Table 5. Muscle mass and daily creatinine excretion and their relationship in eight children who recovered

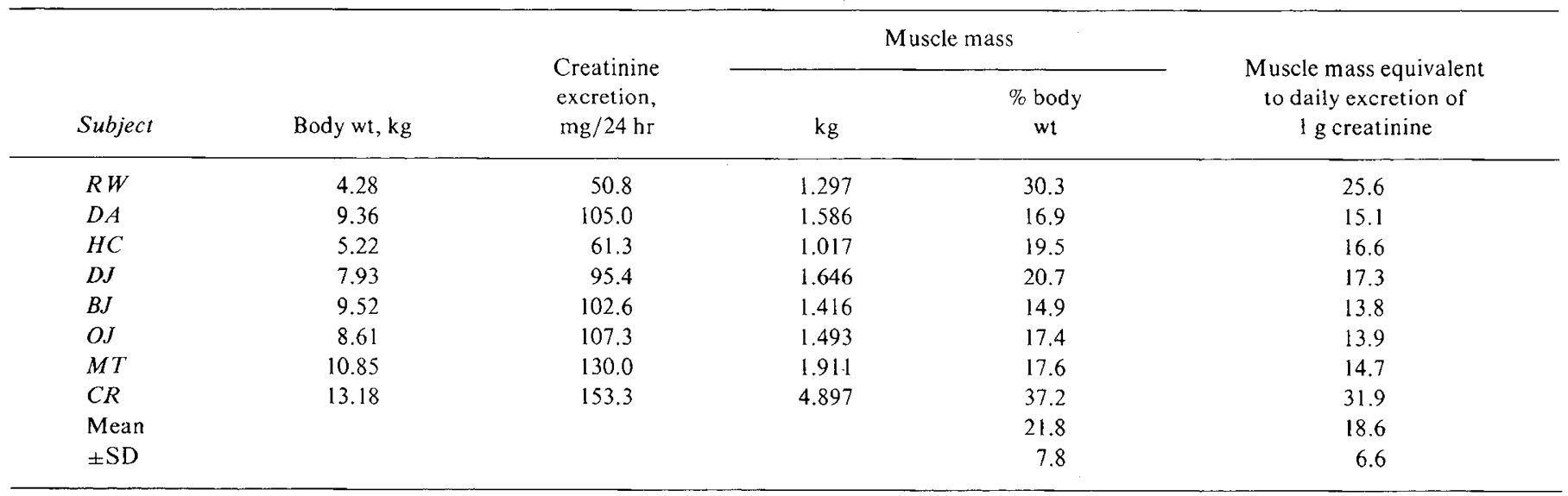


size after measurement of the concentration of creatine in a muscle sample obtained by biopsy. Data are presented to show that labeled creatine equilibrated in the creatinine precursor pool within 3 days, that muscle creatine was the sole precursor of urinary creatinine, and that the turnover rate in the creatine pool was constant during the period of measurement. There appears to be a secondary nonmuscle creatine pool which was much smaller and had a more rapid turnover rate than the muscle creatine pool. The results show that there was wide variation between individuals in creatine turnover and muscle creatine concentration. It is concluded that these variations seriously limit the usefulness of daily creatinine output as a predictor of muscle mass in the individual subject.

\section{REFERENCES AND NOTES}

1. Baldwin, D., Robinson, P. K., Zierler, K. L., and Lilienthal, J. L.: Interrelations of magnesium, potassium, phosphorus and creatine in skeletal muscle of man. J. Clin. Invest., 31: 850 (1952).

2. Bernt, E., Bergmeyer, H. U., and Mullering, H.: Methods of Enzymatic Analysis, p. 407 (Academic Press, New York, 1963)

3. Bloch, K., and Schoenheimer, R.: Studies in protein metabolism. XI. The metabolic relation of creatine and creatinine studied with isotopic nitrogen. $J$. Biol. Chem., 131: 111 (1939).

4. Bloch, K., Schoenheimer, R., and Rittenberg, D.: Rate of formation and disappearance of body creatine in normal animals. $\mathbf{J}$. Biol. Chem., 138: 155 (1941).

5. Borsook, H., and Dubnoff, J. W.: The hydrolysis of phosphocreatine and the origin of urinary creatinine. J. Biol. Chem., 168: 493 (1947).

6. Cheek, D. B., Hill, D. E., Cordano, A., and Graham, G. G.: Malnutrition in infancy; changes in muscle and adipose tissue before and after rehabilitation. Pediat. Res., 4: 135 (1970).

7. Cheek, D. B.: In: Human Growth (Lea \& Febiger, Philadelphia, 1968).

8. Chinn, K. S. K.: Potassium and creatinine as indexes of muscle and nonmuscie protein in rats. J. Nutr., 90: 323 (1966).

9. Chinn, K. S. K.: Prediction of muscle and remaining tissue protein in man. J. Appl. Physiol., 23: 173 (1967).

10. Clarke, L. C., Thompson, H. L., Beck, E. I., and Jacobson, W.: Excretion of creatine and creatinine by children. Amer. J. Dis. Child., 81: 774 (1951).

11. Cocker, W., and Lapworth, A.: A preparation of sarcosine. J. Chem. Soc., 2: 1894 (1931).

12. Ennor, A. H., and Stocken, L. A.: The application of the diacetyl reaction to the estimation of creatine in urine. Biochem. J. 42: 557 (1948).

13. Fitch, C. D., Lucy, D. D., Bornhofen, J. H., and Dalrymple, G. V.: Creatine metabolism in skeletal muscle. II. Creatine kinetics in man. Neurology, 18 : 32 (1968).

14. Fitch, C. D., and Maben, S.: Intestinal loss of creatine by normal and vitamin E-deficient rabbits. Amer. J. Physiol., 207: 627 (1964).

15. Fitch, C. D., Oates, J. D., and Dinning, J. S.: The metabolism of creatine-1 $1{ }^{14} \mathrm{C}$ by mice with hereditary muscular dystrophy. J. Clin Invest., 40: 850 (1961)

16. Garrow, J. S., Fletcher, K., and Halliday, D.: Body composition in severe infantile malnutrition. J. Clin. Invest., 44: 417 (1965).

17. Graystone, J. E.: In: D. B. Cheek: Human Growth, p. 182 (Lea \& Febiger, Philadelphia, 1968)

18. Halliday, D.: Chemical composition of the whole body and individual tissues of two Jamaican children whose death resulted primarily from malnutrition. Clin.
Sci., 33: 365 (1967)

19. Hoberman, H. D., Sims, E. A. H., and Peters, J. H.: Creatine and creatinine metabolism in the normal male adult: Studied with the aid of isotopic nitrogen. J. Biol. Chem., 172: 45 (1948).

20. Kissane, V. M., and Robins, E.: The fluorimetric measurement of deoxyribonucleic acid in animal tissues with special reference to the central nervous system. J. Biol. Chem., 233: 184 (1958).

21. Kreisberg, R. A Bowdoin, B and Meador C. K. Measurement of muscle mass in humans by isotopic dilution of creatine ${ }^{14} \mathrm{C}$. J. Appl. Physiol. 28: 264 (1970)

22. Lowry, O. H., Rosebrough, N. J., Farr, A. L., and Randall, R. J.: Protein measurement with the Folin phenol reagent. J. Biol. Chem., 193: 265 (1951).

23. Meador, C. K., K reisberg, R A., Friday, J. P. Bowdoin, B. Coan, P., Armstrong, J., and Hazelrig, J. B.: Muscle mass determination by isotopic dilution of creatine $-{ }^{14} \mathrm{C}$. Metab. Clin. Exp., 17: 1104 (1968).

24. Myers, V. C., and Fine M. S.: The creatine content of muscle under normal conditions: Its relation to urinary creatinine. J. Biol. Chem., 14:9 (1913).

25. Nichols, B. L., Hazelwood, C. F., and Barnes, D. J.: Percutaneous needle biopsy of quadriceps muscle: Potassium analysis in normal children. J. Pediat., 72: 840 (1968).

26. Patrick, J., Reeds, P. J., Jackson, A. A., and Picou, D.: Total body water in malnutrition: The possible role of energy intake (Submitted for publication). 1975

27. Picou, D., Halliday, D., and Garrow, J. S.: Total body protein, collagen and non-collagen protein in infantile protein malnutrition. Clin. Sci., 30: 345 (1966).

28. Patrick, J: Unpublished data.

29. Robinson, H., Cocks, T., Kerr, D., and Picou, D.: In: L. I. Gardner and P. Amacher: Endocrine Aspects of Malnutrition, p. 45 The Kroc Foundation, Santa Ynez, California (1973).

30. Sprinson, D. B., and Rittenberg, D.: The rate of utilisation of ammonia for protein synthesis. J. Biol. Chem., 180: 707 (1949).

31. Talbot, N. B.: Measurement of obesity by the creatinine coefficient. Amer. J. Dis. Child. 55: 42 (1938)

32. Tanzer, M. L., and Gilvarg, C.: Creatine and creatine kinase measurement. J. Biol. Chem., 234: 3201 (1950).

33. Waterlow, J. C., and Alleyne, G. A. O.: Protein malnutrition in children: Advances in knowledge in the last ten years. Advan. Protein Chem., 25: 117 (1971).

34. Waterlow, J. C., and Mendes, C. B.: Composition of muscle in malnourished human infants. Nature, 180: 1361 (1957).

35. Waterlow, J. C., Neale, R. J., Rowe, L., and Palin, I.: Effects of diet and infection on creatine turnover in the rat. Amer. J. Clin. Nutr., 25: 371 (1972).

36. Azote et Produits Chimiques S. A., 40 Avenue Hoche, Paris (VIII ${ }^{e}$ ) France.

37. Eastman Organic Chemicals, Rochester, N.Y.

38. AEI Scientific Apparatus Ltd., Wembley, Middlesex, England.

39. Vineland, N. J.

40. Excess ${ }^{15} \mathrm{~N}$ is the amount of ${ }^{15} \mathrm{~N}$ in excess of that due to the natural abundance of ${ }^{15} \mathrm{~N}$.

41. We acknowledge the support provided by the Medical Research Council which enabled Dr. P. Reeds to carry out this research.

42. We wish to thank Peter Garlick, Ph.D., for his helpful suggestions, Mrs. Hazel MacDonald and Mrs. Yvonne Gayle for their skilled technical assistance, and Mr. G. Walling for his help in servicing the mass spectrometer.

43. This research was partly supported by the Wellcome Trust who donated the mass spectrometer and provided Dr. A. Jackson and Mr. N. Poulter with Research Fellowships.

44. Requests for reprints should be addressed to: D. Picou, M.B., Ph.D., Director, Tropical Metabolism Research Unit, University of the West Indies, Mona, Kingston 7, Jamaica (W.I.).

45. Accepted for publication November 10, 1975 